\title{
On the Arbitrariness of Consumption
}

\author{
JOHN WHALLEY \\ SHUNMING ZHANG
}

\author{
CESIFO WORKING PAPER No. 2566 \\ CAtegory 2: Public Choice \\ FEBRUARY 2009
}

\footnotetext{
An electronic version of the paper may be downloaded

- from the SSRN website: Www.SSRN.com

- from the RePEc website: $\quad$ www.RePEc.org

- from the CESifo website: www.CESifo-group.org/wp
} 


\title{
On the Arbitrariness of Consumption
}

\begin{abstract}
We discuss a simple model of choices of joint consumption by a working couple who place maintenance of their marriage (relationship) above all else. Any proposal made by one partner seeking to provide maximal utility to the other so as to preserve the marriage, in the case where preferences of partners are unknown, will be accepted. In this sense consumption is arbitrary. In a concluding section we suggest that while overly simple; this structure may characterize to some degree significant amounts of observed consumption, emphasing how social arrangements and the value placed on them by individuals can impact on observed economic behaviour.
\end{abstract}

JEL Code: A10, A12, A13, C50, D01.

Keywords: values, preferences, lexicographic, relationship, partners.

\author{
John Whalley \\ Department of Economics \\ The University of Western Ontario \\ Canada \\ jwhalley@uwo.ca
}

\author{
Shunming Zhang \\ Department of Finance \\ School of Economics \\ Xiamen University \\ P.R. China \\ s.zhang@xmu.edu.cn
}

February 11, 2009

We acknowledge helpful comments by John Piggott, Ray Riezman, Hui Huang and Edgar Cudmore. We acknowledge the financial support from National Social Science Foundation of China (SSFC Grant 07AJL002) and "Humanities and Social Science" Major Projects, Chinese Ministry of Education (Grant Number 07JJD790145). 


\section{Introduction}

Economists have paid relatively little attention to the influence that social value systems can have both on economic behaviour, and our interpretations of observed behaviour for economic policy. This is despite claims from authors in other disciplines that such analyses can have fundamental implications both for behaviour itself and the way economic policy is formulated conditional upon such interpretations. Examples are Sahlins (1972) whose uses anthropological investigations of pre-industrial societies to suggest that even in modern day societies much consumption activity is symbolic rather than for use, and Titmus (1970) whose analysis of blood donation is used to suggest that economies based on gift relationships with no prices or markets are more efficient than conventional market based economies.

Formalizations of models of wider social interaction incorporating economic behaviour, such as those by Hormats (1950) and Simon (1952), generally focus on ways in which social arrangements lead to systems of norms and values in the tradition of Parsons (1932). These are presented in a mathematically formalized setting familiar to economists, rather than in the nuanced verbal discussion common in much sociology literature but do not investigate how social structures condition economic behaviour. Granovetter (1977) also provides a discussion of how economic behaviour and social value systems interact, but again does not provide comparative static results with associated policy implications.

Here, we discuss a specific form of a socially encased model of an economy which is purposefully constructed to yield strong and stark results. In it we assume a population of happily married couples whose dominant interest in life is maintaining their marriages. Individual members of these unions engage in two activities, working and visiting shopping malls where all their combined income in each period is fully spent. Members of the union only know their own utility functions over goods, and have no information on the utility function of their partner. On visiting the shopping mall, both partners can make a proposal as to their joint consumption and they are motivated by the prospective enjoyment of their partner. Thus, if the proposal is that they both buy, say, running shoes when they never go running the other partner immediately accepts. In this sense, consumption in this economy is arbitrary even though each individual has a utility function over goods and behaviour is optimizing, since preservation of the social relationship (marriage) lexicographically dominates utility form consumption of goods.

In what follows, we first present a simple formalization of a model embodying this idea and demonstrate that the solution concept implies arbitrary consumption. We also suggest that, 
while behaviour in reality is much more complex, this form of consumption may be seen in practice in consumption expenditures on Christmas and other gifts, expenditures on items such as food and clothing for other family members, and other socially encased economic behaviour. We also draw out some policy implications of the model, including the absence of any dead weight costs of taxation and the seemingly large potential welfare benefits (in a consumption sense) of divorce. In a final section, we speculate on some possible elaborations of the model to include sequential learning of preferences of partners both in an overlapping generations structure and in infinitely lived consumer recursive dynamics.

\section{A Marriage-Shopping Mall Model}

We consider a world where there are $2 N$ individuals. At the beginning of the period they are all in marriages, and their primary objective is to remain in their union at the end of the period. Unions involve $N$ pairs of individuals which we index $j=1,2$. We assume that while members of such unions are oppositely sexed, the objective of procreation does not enter either preferences or strategic behaviour. Their strategy for remaining in their chosen union is simply to maximize their partner's utility from goods consumption in the hope that higher goods utility will raise the chance of the marriage surviving, and they also minimize conflict by agreeing to whatever their partner proposes.

Individuals in each union are assumed to consume goods $X_{l}^{n j}$, where $l=1, \cdots, L$ denotes each of $L$ commodities, $n$ denotes the union $(n=1, \cdots, N)$, and $j$ denotes the individual $(j=1,2)$. We assume each member of the union works in period $t$ and receives income $I^{n j}$ (we suppress the subscript for simplicity). Work decisions are exogenous. The union income in the period in this is given by $\sum_{j=1}^{2} I^{n j}$.

We assume each individual in each union has a utility function from goods consumption which we write as

$$
U^{n j}\left(X^{n j}\right)
$$

where $X^{n j}$ denotes the vector $\left(X_{1}^{n j}, \cdots, X_{L}^{n j}\right)$. All consumption expenditures are decided upon jointly by couples in a single visit to the shopping mall made each period. Individual members of the union are allowed to make proposals to the other member of the union as to how they should jointly allocate their income to the expenditure of goods. The only restriction is that the union budget constraint be satisfied. 
The union budget constraint for the period can be written as

$$
\sum_{j=1}^{2} I^{n j}=\sum_{l=1}^{L} \sum_{j=1}^{2} P_{l} X_{l}^{n j} .
$$

For simplicity, we assume that all consumption proposals made involve joint and identical consumption of goods consistent with (2.2), ie.,

$$
X_{l}^{n 1}=X_{l}^{n 2}
$$

Thus proposals are made that each partner jointly consume, say, an apple or a pear. This restriction can be relaxed.

Each union member is assumed to have a preference ordering over both utility from goods consumption and preservation of their marriage which is lexicographic in marriage preservation. They also believe that a partner receiving higher utility from goods consumption is more likely to remain in the marriage. They therefore seek to minimize conflict between union members so as to preserve marital bliss, and their objective of providing maximal utility from goods consumption for the other union member they meet by guessing at their preferred consumption. In the absence of any information as to the preferences of the partner any proposal of the form (2.3) consistent with (2.2) will be immediately accepted by the other union member.

We denote $M^{n j}$ to be the marriage of pair $n$ that individual $j$ attempts to preserve. The preference ordering of individual $i$ in pair $n$ is $V^{n j}\left(M^{n j}, U^{n j}\left(X^{n j}\right)\right)$ for $j=1,2$. We assume that the preference ordering $V^{n j}$ is lexicographic and $M^{n j}$ dominates $U^{n j}\left(X^{n j}\right)$. Individual $j=1,2$ also believes that, the larger $U^{n, 3-j}\left(X^{n, 3-j}\right)$, the higher $M^{n j}$. Thus we can write the lexicographic preference ordering for all individuals as ${ }^{1}$

$$
V^{n j}\left(U^{n, 3-j}\left(X^{n, 3-j}\right), U^{n j}\left(X^{n j}\right)\right), \quad n=1, \cdots, N ; \quad j=1,2 .
$$

We assume that neither partner knows the utility function over goods of the other partner. Thus, for $j=1,2$, individual $j$ does not know $U^{n, 3-j}\left(X^{n, 3-j}\right)$. Thus if partner $j$ has a diffuse prior (or a uniform prior) on $U^{n, 3-j}\left(X^{n, 3-j}\right)$ or $U^{n j}\left(X^{n j}\right)$, they make random proposals for consumption, and the other partner accepts. Thus, each individual $j$ in union $n$ faces the following utility maximization problem

$$
\begin{array}{ll}
\max & V^{n j}\left(U^{n, 3-j}\left(X^{n, 3-j}\right), U^{n j}\left(X^{n j}\right)\right) \\
\text { s.t. } & \sum_{l=1}^{L} \sum_{j=1}^{2} P_{l} X_{l}^{n j}=\sum_{j=1}^{2} I^{n j}
\end{array}
$$

\footnotetext{
${ }^{1}$ This lexicographic preference ordering is not, however, continuous.
} 
which gives the diffuse prior on $V^{n j}$ implies that individual makes a random proposal for consumption.

In this sense, therefore, consumption behaviour in this economy is arbitrary. Any proposal for joint and similar consumption behaviour by each couple is accepted both members, independently of their own preferences. In this economy, economic behaviour can seem irrational but is sustained by socially encased optimizing behaviour of individuals where persuit of marriage preserving objectives dominates individual benefits from the use of commodities.

Two implications which follow from this model are that the dead weight loss of taxation will be zero, and that potentially significant consumption (or goods) welfare gains will accrue from divorce. This follows because consumption activity in the presence of taxation (assuming that revenues from commodity specific taxes are returned in lump sum form to consumers) remains the same. With consumption proposals and their joint acceptance, provided the union holds, the welfare from remaining married is unaffected by taxes. Equally, the utility consumption gains from divorce (ignoring the loss from marriage break down) could potentially be large in this structure since separate consumption decision would involve individual budget constraints, and individually based utility maximization of goods consumed.

\section{Empirical Implications and Possible Model Extensions}

While extremely simple, this model seemingly has disturbing empirical implications. How much consumption behaviour in practice is of the type suggested here is unknown from available data, since consumer survey data only reports consumption expenditure by category (eg. food, clothing), not by purchaser (individual or couple). But much consumption would seem to be undertaken by individual family members on behalf of other family members. This includes Christmas gift expenditures (sometimes put at $25 \%$ of annual expenditures on durables, see Waldfogel (1997)), other gifts, expenditures on food, clothing, holidays, cars and many other items. Socially encased consumption is not a concept finding empirical analogues in national income accounts and other data sources, but perhaps it should.

This simple model is also stark and deliberately so, so as to forcefully show its conclusions and implications, and models with sequential learning and preference revelation would seemingly weaken its force. And it would seem an over simplification to suggest that couples can live together for, say, 40 years without gaining at least some knowledge of each other's likes and dislikes. Equally, parents' imputations of preferences of children are likely follow a related 
sequence of discovery (and change). Thus model extensions to incorporate an overlapping generations structure where over time newly married couples discover more of each others likes and dislikes would seem a natural weakening extension. And equally similar weaker conclusions would likely follow from an infinitely lived couples (and individuals) modeling approach with recursive dynamics.

Whether social arrangements differ enough from society to society that different models of encasement make more sense for different economies is left as an open issue. Do, say, Chinese marriages differ enough from American marriages that distinctive forms of social encasement, and hence societal specific representations, are appropriate. To the extent that societies are distinct, economists might thus be well advised to move away from completely general models claiming to represent all societies and perhaps to groupings of social structures (traditional / non-traditional or Asia / non-Asia, for instance), or even to more specific representations (Thailand, Argentina, New York or Manhattan, for instance).

Social encasement of economic behaviour seems clearly important comparing, says, Chinese to OECD behaviour where collective identity to family, village, town, province, and China seemingly drive acceptance of responsibility by individual Chinese, and result in much hard work and creative energy. Indeed, an extreme characterization of the Chinese economy might be as joint collective commitment not to repeat the political and social instability which has characterized Chinese history for 10,000 years, or longer. Growth though hard work is the modern Chinese collective response to hopefully ensuring an absence of social meltdown. As such high growth in modern China may reflect collective commitment with the resulting social encasement heavily determining individual economic behaviour.

The theme of this short paper, then, is that socially encased economic behaviour if explicitly modeled may lead to sharply different interpretations of that behaviour economists are used to. Literature on such social encasement seems sparse and little developed. Extensions of the form and type of economies would seem productive for richer and deeper analytics to follow.

\section{References}

[1] Granovetter M. (1977), Social Networks: A Developing Paradigm, Academic Press.

[2] Hormans G. C. (1950), The Human Group, New York, Harpers.

[3] Parsons T. (1937), Structure of Social Action. New York: Free Press. 
[4] Sahlins M. (1972), Stone Age Economics, Chicago, Aldine.

[5] Simon H. A. (1952), A Formal Theory of Interaction in Social Groups, American Sociological Review 17 (2): 202-211.

[6] Simon H. A. (1997), Models of Bounded Rationality: Empirically Grounded Economic Reason, Cambridge, Massachusetts: MIT Press.

[7] Titmuss R. M. (1970), The Gift Relationship: From Human Blood to Social Policy, Publisher London, Allen and Unwin.

[8] Waldfogel J. (1993), The Deadweight Loss of Christmas, American Economic Review 83 (5): 1328-1336. 


\section{CESifo Working Paper Series}

for full list see www.cesifo-group.org/wp

(address: Poschingerstr. 5, 81679 Munich, Germany, office@cesifo.de)

2505 Wenan Fei, Claude Fluet and Harris Schlesinger, Uncertain Bequest Needs and LongTerm Insurance Contracts, December 2008

2506 Wido Geis, Silke Uebelmesser and Martin Werding, How do Migrants Choose their Destination Country? An Analysis of Institutional Determinants, December 2008

2507 Hiroyuki Kasahara and Katsumi Shimotsu, Sequential Estimation of Structural Models with a Fixed Point Constraint, December 2008

2508 Barbara Hofmann, Work Incentives? Ex Post Effects of Unemployment Insurance Sanctions - Evidence from West Germany, December 2008

2509 Louis Hotte and Stanley L. Winer, The Demands for Environmental Regulation and for Trade in the Presence of Private Mitigation, December 2008

2510 Konstantinos Angelopoulos, Jim Malley and Apostolis Philippopoulos, Welfare Implications of Public Education Spending Rules, December 2008

2511 Robert Orlowski and Regina T. Riphahn, The East German Wage Structure after Transition, December 2008

2512 Michel Beine, Frédéric Docquier and Maurice Schiff, International Migration, Transfers of Norms and Home Country Fertility, December 2008

2513 Dirk Schindler and Benjamin Weigert, Educational and Wage Risk: Social Insurance vs. Quality of Education, December 2008

2514 Bernd Hayo and Stefan Voigt, The Relevance of Judicial Procedure for Economic Growth, December 2008

2515 Bruno S. Frey and Susanne Neckermann, Awards in Economics - Towards a New Field of Inquiry, January 2009

2516 Gregory Gilpin and Michael Kaganovich, The Quantity and Quality of Teachers: A Dynamic Trade-off, January 2009

2517 Sascha O. Becker, Peter H. Egger and Valeria Merlo, How Low Business Tax Rates Attract Multinational Headquarters: Municipality-Level Evidence from Germany, January 2009

2518 Geir H. Bjønnes, Steinar Holden, Dagfinn Rime and Haakon O.Aa. Solheim, ,Large’ vs. ,Small' Players: A Closer Look at the Dynamics of Speculative Attacks, January 2009

2519 Jesus Crespo Cuaresma, Gernot Doppelhofer and Martin Feldkircher, The Determinants of Economic Growth in European Regions, January 2009 
2520 Salvador Valdés-Prieto, The 2008 Chilean Reform to First-Pillar Pensions, January 2009

2521 Geir B. Asheim and Tapan Mitra, Sustainability and Discounted Utilitarianism in Models of Economic Growth, January 2009

2522 Etienne Farvaque and Gaël Lagadec, Electoral Control when Policies are for Sale, January 2009

2523 Nicholas Barr and Peter Diamond, Reforming Pensions, January 2009

2524 Eric A. Hanushek and Ludger Woessmann, Do Better Schools Lead to More Growth? Cognitive Skills, Economic Outcomes, and Causation, January 2009

2525 Richard Arnott and Eren Inci, The Stability of Downtown Parking and Traffic Congestion, January 2009

2526 John Whalley, Jun Yu and Shunming Zhang, Trade Retaliation in a Monetary-Trade Model, January 2009

2527 Mathias Hoffmann and Thomas Nitschka, Securitization of Mortgage Debt, Asset Prices and International Risk Sharing, January 2009

2528 Steven Brakman and Harry Garretsen, Trade and Geography: Paul Krugman and the 2008 Nobel Prize in Economics, January 2009

2529 Bas Jacobs, Dirk Schindler and Hongyan Yang, Optimal Taxation of Risky Human Capital, January 2009

2530 Annette Alstadsæter and Erik Fjærli, Neutral Taxation of Shareholder Income? Corporate Responses to an Announced Dividend Tax, January 2009

2531 Bruno S. Frey and Susanne Neckermann, Academics Appreciate Awards - A New Aspect of Incentives in Research, January 2009

2532 Nannette Lindenberg and Frank Westermann, Common Trends and Common Cycles among Interest Rates of the G7-Countries, January 2009

2533 Erkki Koskela and Jan König, The Role of Profit Sharing in a Dual Labour Market with Flexible Outsourcing, January 2009

2534 Tomasz Michalak, Jacob Engwerda and Joseph Plasmans, Strategic Interactions between Fiscal and Monetary Authorities in a Multi-Country New-Keynesian Model of a Monetary Union, January 2009

2535 Michael Overesch and Johannes Rincke, What Drives Corporate Tax Rates Down? A Reassessment of Globalization, Tax Competition, and Dynamic Adjustment to Shocks, February 2009 
2536 Xenia Matschke and Anja Schöttner, Antidumping as Strategic Trade Policy Under Asymmetric Information, February 2009

2537 John Whalley, Weimin Zhou and Xiaopeng An, Chinese Experience with Global 3G Standard-Setting, February 2009

2538 Claus Thustrup Kreiner and Nicolaj Verdelin, Optimal Provision of Public Goods: A Synthesis, February 2009

2539 Jerome L. Stein, Application of Stochastic Optimal Control to Financial Market Debt Crises, February 2009

2540 Lars P. Feld and Jost H. Heckemeyer, FDI and Taxation: A Meta-Study, February 2009

2541 Philipp C. Bauer and Regina T. Riphahn, Age at School Entry and Intergenerational Educational Mobility, February 2009

2542 Thomas Eichner and Rüdiger Pethig, Carbon Leakage, the Green Paradox and Perfect Future Markets, February 2009

2543 M. Hashem Pesaran, Andreas Pick and Allan Timmermann, Variable Selection and Inference for Multi-period Forecasting Problems, February 2009

2544 Mathias Hoffmann and Iryna Shcherbakova, Consumption Risk Sharing over the Business Cycle: the Role of Small Firms' Access to Credit Markets, February 2009

2545 John Beirne, Guglielmo Maria Caporale, Marianne Schulze-Ghattas and Nicola Spagnolo, Volatility Spillovers and Contagion from Mature to Emerging Stock Markets, February 2009

2546 Ali Bayar and Bram Smeets, Economic and Political Determinants of Budget Deficits in the European Union: A Dynamic Random Coefficient Approach, February 2009

2547 Jan K. Brueckner and Anming Zhang, Airline Emission Charges: Effects on Airfares, Service Quality, and Aircraft Design, February 2009

2548 Dolores Messer and Stefan C. Wolter, Money Matters - Evidence from a Large-Scale Randomized Field Experiment with Vouchers for Adult Training, February 2009

2549 Johannes Rincke and Christian Traxler, Deterrence through Word of Mouth, February 2009

2550 Gabriella Legrenzi, Asymmetric and Non-Linear Adjustments in Local Fiscal Policy, February 2009

2551 Bruno S. Frey, David A. Savage and Benno Torgler, Surviving the Titanic Disaster: Economic, Natural and Social Determinants, February 2009

2552 Per Engström, Patrik Hesselius and Bertil Holmlund, Vacancy Referrals, Job Search, and the Duration of Unemployment: A Randomized Experiment, February 2009 
2553 Giorgio Bellettini, Carlotta Berti Ceroni and Giovanni Prarolo, Political Persistence, Connections and Economic Growth, February 2009

2554 Steinar Holden and Fredrik Wulfsberg, Wage Rigidity, Institutions, and Inflation, February 2009

2555 Alexander Haupt and Tim Krieger, The Role of Mobility in Tax and Subsidy Competition, February 2009

2556 Harald Badinger and Peter Egger, Estimation of Higher-Order Spatial Autoregressive Panel Data Error Component Models, February 2009

2557 Christian Keuschnigg, Corporate Taxation and the Welfare State, February 2009

2558 Marcel Gérard, Hubert Jayet and Sonia Paty, Tax Interactions among Belgian Municipalities: Does Language Matter?, February 2009

2559 António Afonso and Christophe Rault, Budgetary and External Imbalances Relationship: A Panel Data Diagnostic, February 2009

2560 Stefan Krasa and Mattias Polborn, Political Competition between Differentiated Candidates, February 2009

2561 Carsten Hefeker, Taxation, Corruption and the Exchange Rate Regime, February 2009

2562 Jiahua Che and Gerald Willmann, The Economics of a Multilateral Investment Agreement, February 2009

2563 Scott Alan Carson, Demographic, Residential, and Socioeconomic Effects on the Distribution of $19^{\text {th }}$ Century US White Statures, February 2009

2564 Philipp Harms, Oliver Lorz and Dieter Urban, Offshoring along the Production Chain, February 2009

2565 Patricia Apps, Ngo Van Long and Ray Rees, Optimal Piecewise Linear Income Taxation, February 2009

2566 John Whalley and Shunming Zhang, On the Arbitrariness of Consumption, February 2009 